\title{
Smart Indoor Navigation System: INCREDISCOPE
}

\section{Paweł Dominik, Jacek Marcinkowski}

UNISYSTEM Sp. z 0.0., ul. Nowy Świat 36, 80-299 Gdańsk

\begin{abstract}
The paper presents a newly developed, innovative idea on a global scale system for indoor navigation INCREDISCOPE. The system is fully autonomic, and it is based on e-paper displays technology. The original positioning and navigation system for people inside buildings gives the possibility to intuitively and naturally lead a person to the desired destination. The paper consists of four parts. In the beginning, the short introduction and basic assumptions about indoor navigation and positioning are given. Then the core idea of the system and basic assumptions are introduced. In the third section, some technical information of prepared software is presented. Three different applications were prepared - intended for the system administrator; designated for e-paper displays and a mobile application for users who move inside buildings with their smartphones. The recognition of the users is based on Bluetooth technology. In the paper, two versions of the administrator interface were presented (Admin 1.0 and Admin 2.0). The operation logic of each version is completely different. The first one was too time-consuming during relations table creation. The second one is more intuitive. The last part of the article includes conclusions and prospects for further development of the system.
\end{abstract}

Keywords: e-paper, Bluetooth, user recognition, autonomic system, indoor positioning, indoor navigation

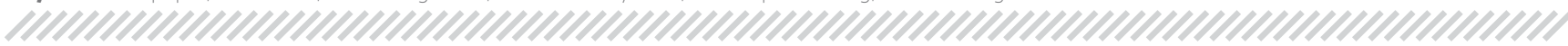

\section{Introduction}

Currently, the most common indoor navigation method is based on static plans, boards, and signposts, which are located in a limited number of places, often poorly visible. Furthermore, the change of destination of the person or possible routes can occur. Such a situation is persistent in large buildings with many floors and rooms, like offices, hospitals, or universities. For example, the location of the conference room can change. Described situations illustrate the limitations resulting from the method of static information presentation.

A more modern method of indoor person navigation is information presented on LCD/LED displays. The advantages of this method are maintenance-free, 24 hours availability, and flexibility to change of information. This method's main drawbacks are: high price, need for additional power supply infrastructure, and a limited number of screens (usually several screens installed at the entrances).

Autor korespondujący:

Paweł Dominik, pawel.dominik@unisystem.pl

Artykuł recenzowany

nadesłany 16.11 .2020 r., przyjęty do druku 04.02.2021 r.
The most modern method of indoor navigation is navigation using interactive maps in smartphones. In such a method, the person is positioned using a GSM signal, a Wi-Fi/Bluetooth signal triangulation, or a dedicated beacon. An example of such system is the Maze Map [1, 2]. The significant advantage of this type of system is interactivity and ease of modifying presented information. There are also disadvantages to this method. The main drawback is the accuracy of user positioning. Moreover, disabled people can have a problem with simultaneous moving inside the building and watching the screen of the smartphone (the map is continuously displayed). Finally, it is worth mentioning that the method requires accurate map of the whole building, which can be very expensive.

The above-shortened analysis showed that the currently used indoor navigation systems have numerous disadvantages and do not meet users' expectations. Considering the above, the presented in the next section idea of system INCREDISCOPE will eliminate the drawbacks of previously presented manners of indoor people navigation. The INCREDISCOPE is autonomous, energy-saving, wireless, intuitive, and fully meets each user's expectations. Thanks to autonomic e-paper displays installed on each crossing and strategical points in the building, it will be possible, which will recognize individuals and give them personalized, simple instruction of further movement. The presented system does not require any additional investments from the building administrator, but only the preparation of the building's simplified map. 


\section{Basic assumptions and an idea of INCREDISCOPE system}

The main assumptions of the INCREDISCOPE system are listed below:

- System should give personalized information about the way how to get the destination;

- Information is presented on e-paper displays located in crucial points of the building;

- The usage of the system should be intuitive and comfortable, even for people unfamiliar with new technology;

- System devices (displays) should allow easy deployment in the building and simple system configuration thanks to wireless communication, energy saving, and mobility.

In the user view, INCREDISCOPE consists of a given number of devices (displays), which present personalized navigation instructions for each user. The instruction should be presented on display when the user gets the crucial point with the navigation display. It follows that the location task can be treated as a task of proximity detection and user identification. Security of user identification, normative and legal regulations, mechanical and energetic requirements were also considered.

The most popular technologies used in Indoor Localization/ Positioning Systems ILS/IPS [3-6] are WLAN/Wi-Fi, Inertial Measurement Units (IMU), Bluetooth (smartphones and beacons), Ultra-WideBand (UWB) communication. ILS/IPS based on the first three technologies are the most common because they are practically available in each modern smartphone. This fact shows the possibility of creating an application for users' smartphones without investing in additional equipment for users.

In order to select the proximity detection technology, the authors carry out experimental tests. Several WiFi and Bluetooth modules were tested in different conditions - simulating ideal conditions (without interference and physical barriers), and in similar to real ones, where there are interference and physical barriers. Bluetooth modules showed many advantages in comparison to WiFi modules. Finally, the Bluetooth Low Energy (BLE) technology was chosen, and the following arguments support this decision:

- low cost (users' smartphones and BLE beacons),

- low energy consumption (one or two orders of magnitude compared to WLAN),

- low range (few meters) - ideally for proximity detection,

- high availability of BLE modules intended for use in device construction.

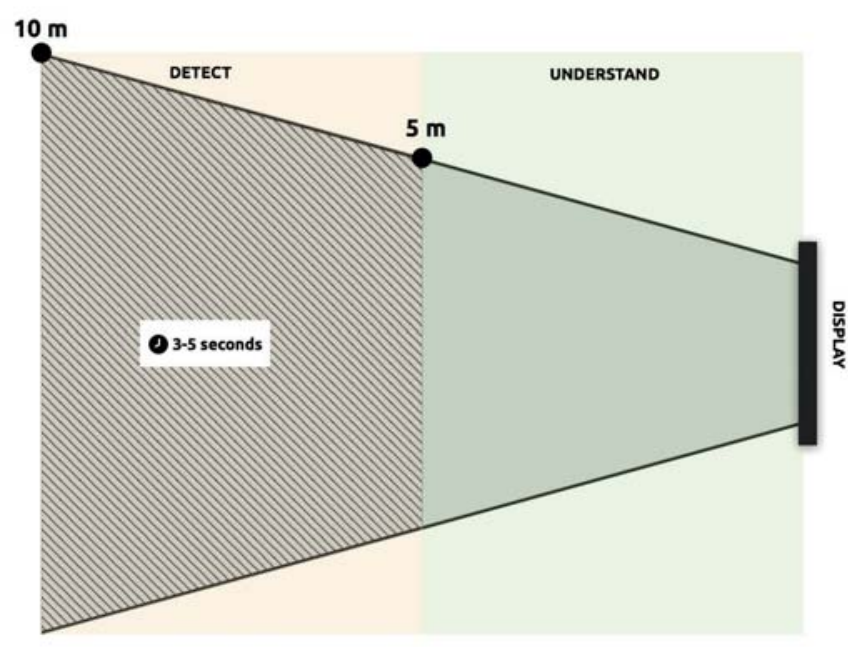

Fig. 1. Illustration of the situation, when the navigated person is approaching the display

Rys. 1. Zobrazowanie sytuacji, w której nawigowana osoba zbliża się do wyświetlacza
Some crucial assumptions were made during the realization of the project. The authors describe those assumptions in the following paragraphs.

The navigation system should operate based on the 7-second rule. It means that the system must allow the navigated person to orientate themselves in the space in no more than 7 seconds; otherwise, they feel stress and discomfort.

The mobile application for users should be as simple as possible. The symbols on the e-paper screens should also be easy to understand (turn left, turn right, move forward, move backward, change the floor using stairs or elevator). This type of symbol is compatible with recommendations of the American Institute of Graphic Arts (AIGA). They are used by authorities and many organizations, such as airports, hospitals, and other public places. Therefore, they are easily recognizable and user-friendly. The use of simple symbols on the displays is possible thanks to their intelligent arrangement inside the building. One of the essential guidelines that should be followed is to ensure that the movement direction change should occur at an angle of 90 degrees. Orientation in space is easier when the navigated person changes the direction by 90 degrees. It is better to use simple symbols with one meaning than complex symbols with more than one meaning. This approach makes it easier to understand the meaning of the symbols presented on the displays. The navigated person has to decode and remember only one symbol on each display.

Figure 1 shows the situation schematically when the navigated person approaches the display with the instruction about further movement direction. To effectively navigate people inside buildings, each display must be easily visible from a certain distance. The authors assumed that the symbols on display should be noticed from 10 meters and understand from a distance of 5 meters. It corresponds to $3-5$ seconds of walking towards the display. During this time, symbols and information on the display should be visible and understandable so that the user can change their movement direction if necessary.

The navigated person is connected with the instruction on display intended for her using the specified number associated with the meeting instead of the person. This approach ensures the security of personal data.

The first version of the system (Admin 1.0) indoor navigation task was described using a matrix of the destinations and crucial points where displays are installed. For each matrix's intersection, the instruction of further movement is given. This approach was too complicated due to the lack of space representation and very time-consuming matrix filling by the system administrator.

In the second version of the system, indoor navigation was described using a map of relations between displays and destinations presented in the graphical administrator interface (Admin 2.0).

\section{Prepared software}

Three different software components were prepared during the INCREDISCOPE project realization. The first one is prototype software dedicated to mobile devices (versions for Android and $\mathrm{iOS}$ ). The second one is prototype software dedicated to e-paper displays, which are responsible for the users' indoor navigation. The third software component is a prototype application for the navigation system administrator. This application, among other things, allows setting up relations between displays and destinations in the building of interest.

In the fig. 2 it is seen that the direct interaction between user and application is not possible. The navigation identifier view is only available. The EU personal data security law is assured thanks to this identifier. Modern smartphones limit the opera- 
tion of applications in the background due to the limitation of energy consumption. The authors put effort into running the application in the background. This solution allows the application to run in the background even when the phone is in the pocket (and the user is not looking at the application screen).

In the fig. 3 the exemplary interface implemented on e-paper displays is presented. Tests of displays have shown that the use of greyscale is problematic in terms of visibility and contrast. This problem was solved by using an entirely monochrome interface. Authors proposed using two different e-paper screen dimensions - 13" and 32". The first one can show maximally six rectangles with information about how to get to the specified event/meeting. The second one can serve up to nine rectangles with this kind of information. Those numbers of rectangles are strictly connected with assumptions that the symbols on display should be noticed from 10 meters and understand from

$13: 431$

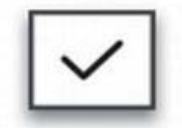

\section{Connected (2)}

Follow your unique event number across all displays.

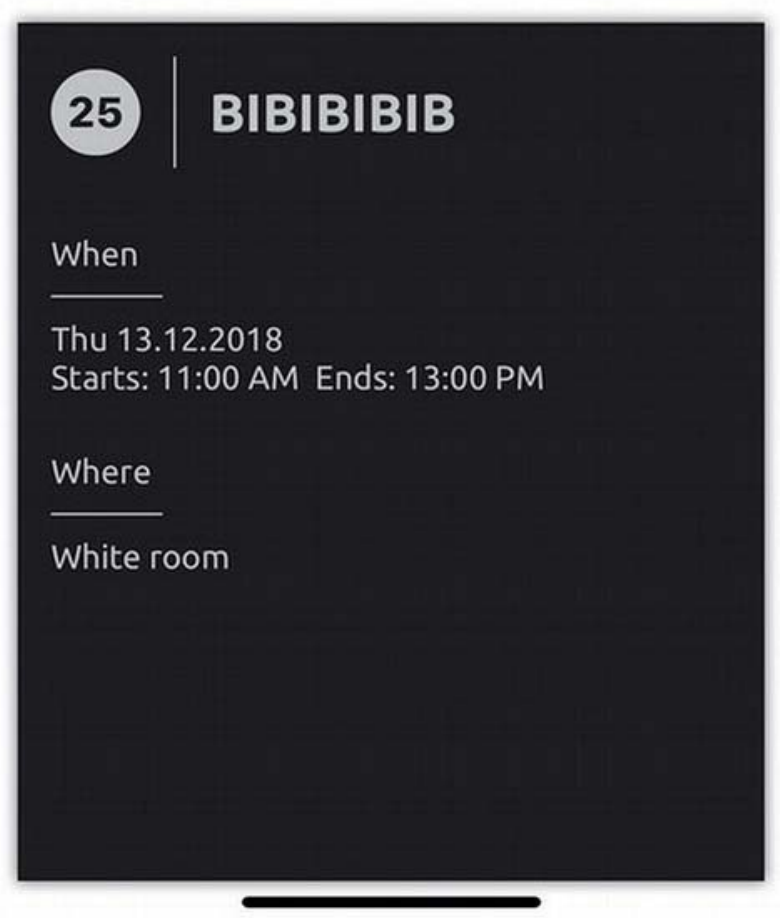

Fig. 2. Screenshot from the iOS smartphone with running INCREDISCOPE application

Rys. 2. Zrzut ekranu ze smartfona z systemem iOS z uruchomioną aplikacją INCREDISCOPE a distance of 5 meters. There is a possibility to add a greater number of events under the appropriate symbols of further movement in larger displays.

In the first version of the administrator's interface (Admin 1.0), the easiest solution was chosen. Each display and each destination were treated as one connection. It means that for each destination, the appropriate pictogram should be chosen for each display in the given system. The Admin 1.0 panel was useful if the number of displays and destinations was not greater than 5 . In the case of a larger number, using the interface required much manual work when entering connections and a lot of the administrator's spatial orientation skills. The administrator's responsibility is to understand the display location and its orientation to the given destination. For example, with ten possible destinations and five displays in the system, fifty unique combinations of displayed symbols had to be manually entered. This approach meant that there was no easy way to train the self-mapping system.

In many cases, there are destinations in the same area that do not require manual configuration of the information displayed on each display. Based on those experience from the Admin 1.0 interface few conclusions were drawn: the interface is tough to use in large buildings with many rooms and floors; the increase of destinations and displays cause the increase of possible connections which should be configured manually; there is lack of chance to learning and suggesting possible connections based on other similar routes. There was a clear need to create a new admin interface that could be used in larger buildings. It was appropriate to prepare an interface that allows the system's administrator to enter relationships and navigation hints using a graphical tool (GUI).

The authors decide to carry out further research and development work. The consequence of that work was developing a new idea of administrator's interface, called Admin 2.0. In the fig. 4 screenshot from Admin 2.0 application is presented.

By changing the navigation logic to point-to-point navigation, the system can be trained to predict at least $80 \%$ of directions (symbols shown on the displays) if the destination is near other already mapped destinations. A search for a similar point-to-point model in the real world and other digital products began. Based on conversations with users, it has been discovered that most of them describe the way to their destination in a point-to-point manner. For example: "Turn left at the intersection, then walk about 200 meters straight until you see your destination on the right". This thought experiment showed that we think from landmark to landmark,

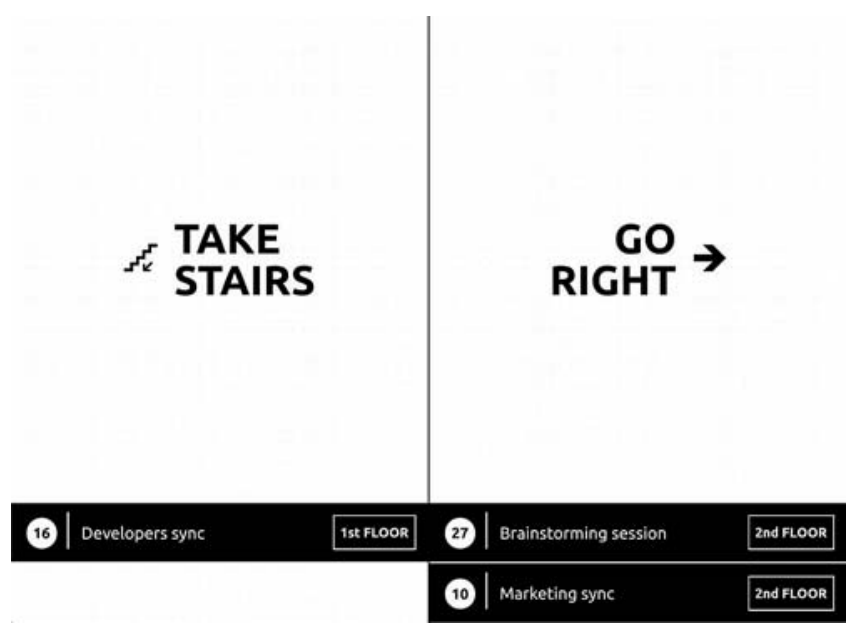

Fig. 3. Exemplary interface implemented on e-paper displays Rys. 3. Przykładowy interfejs zaimplementowany na module z wyświetlaczem e-papier 
which goes against the logic of Admin 1.0 - each landmark relative to a destination. In fig. 5 , a new logic of creating relations between landmarks in Admin 2.0 and the logic used in Admin 1.0 is shown.

The Admin 2.0 interface has been adapted mainly for configuring larger buildings with multiple displays and destinations. To minimize the administrator's work when configuring the system, the system configuration logic was created in the form of a diagram. Thanks to this approach, the administrator introduces a diagram instead of entering all possible navigation instructions. Relations between nodes will be used to calculate the next optimal point of the optimal route. It was

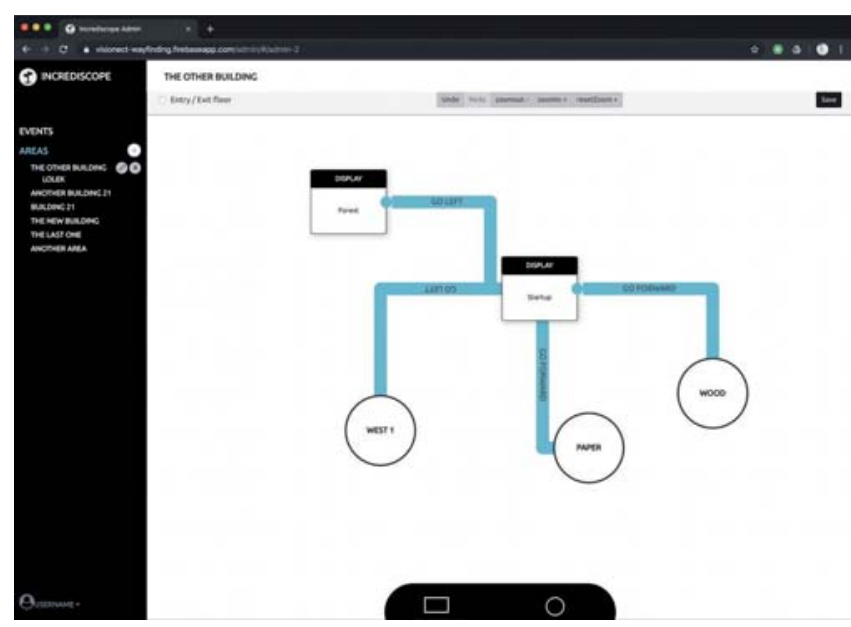

Fig. 4. Administrator's interface (Admin 2.0) allows entering relationships using a graphical tool

Rys. 4. Interfejs administratora (Admin 2.0) umożliwiający ustalanie relacji między węzłami nawigacji przy użyciu narzędzia graficznego

deliberately decided not to complicate the connections between each floor or each building. It would require that all possible connections be configured between each entry point of all floors and all buildings.

Therefore, when the navigated person has to move between floors or buildings, it only gets a simple instruction (on display at the entry point) without pointing to a specific direction.

The main entities used to calculate the user's next way-point are building/area, floor/logical part of a building, display node, destination node, link/connection.

Building or area represents a whole physical building or any logical union of physically or logically connected spaces and serves as a parent of those. Buildings/Areas are in a sibling relationship but are not directly connected. It would require more complexity on the administrator part; therefore, a navi-

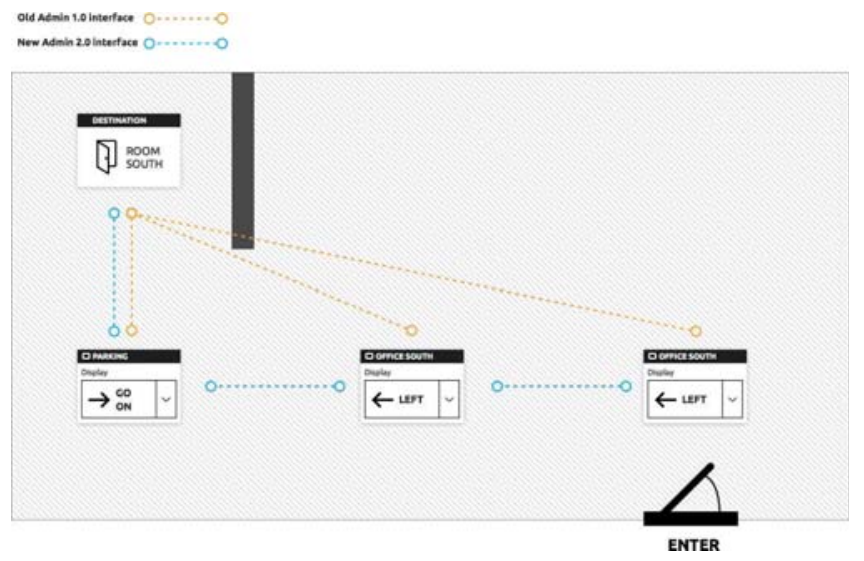

Fig. 5. Differences in the logic of the Admin 1.0 and Admin 2.0 interface Rys. 5. Różnice w logice działania interfejsów Admin 1.0 oraz Admin 2.0 gation instruction between buildings would read as "Go to [building name]".

Floors are logical or physical parts of a building/area that hold the critical navigation information - diagramm of screen and destination nodes. Floors are also in a sibling relationship but are not directly connected. Each floor holds at least one entry node, representing a node that is the last way-point on that floor - usually used as an instruction to switch floors/ buildings. Since a building can hold many floors, at least one floor must be marked as an entry floor - this floor is used to transition the user between buildings. Suppose a user is currently on a floor which is not marked as an entry floor, and the user's destination is another building. In that case, the system will first navigate that user to the current building's entry floor, which is the only possible transition point. A building can hold multiple entry floors - the closest will be used as the next way-point.

Display nodes, as the name suggests, represent actual displays. They can connect to other displays - to form a repeating chain or to final destinations. All nodes are connected in an unweighted diagram; displays can be connected bi-directional (how to transition from and to another display). Display nodes can be marked as entry nodes.

Destination nodes represent physical destinations and can connect only to display nodes. Links are connections between two nodes that can either be of display or destination types. Links contain information about the direction to take between the nodes.

The navigation logic in the Admin 2.0 interface can be summarized in the following statements:

- the user is detected in front of the display node,

- the current floor is found based on the user's location and information about the user's destination,

- based on the information about the user's destination the target floor is found,

- based on the information about the destination to which the user goes, the shortest route to the destination is determined,

- based on the shortest route, information about the next intermediate point on the route is sent to the display in front of which the user is located,

- the above logic continues until the user reaches the destination.

\section{Conclusions}

Authors present details of prepared software for indoor navigation. It is worth to emphasized that the realized project had developmental nature. This type of indoor navigation system with such sophisticated parameters and features is not available on the market. Thus, it was necessary to develop it from scratch.

Appropriate integration interfaces between the individual software components have been prepared, combining them into a comprehensive system using the server approach. The system integration consisted of combining all previously prepared components: the administrator interface, the routing module, the module with an e-paper display and wireless BLE communication interface, and the user's application for mobile phones. After the final integration of the previously prepared components into a working system and the system's final configuration, it was tested in practical use in an actual building. The tests were divided into two scenarios created inside the company's building (the office allows to simulate a larger building), and they were tested together with the employees. During the tests, the users' available set of mobile phones (10 different 
mobile phone models, including Samsung, Huawei, Apple, LG) were used. Based on the test results, the necessary software corrections were prepared. The testing phase was smaller than initially planned. It was due to the limitations resulting from the pandemic and the need to limit contact between people. As a result of the performed tests, no significant defects of the designed software's system and interfaces were noticed. Therefore, there were no radical changes in the graphical interfaces, except for corrections in the application's layout based on feedback from users during tests.

Despite the research and development work, the overview of the legal aspects was done. Results show that accurate risk management and ensuring the protection of personal data is a vital task. It is worth introducing an international ISO 27001 cybersecurity standard to comply with the European Union law. It will ensure continuous monitoring and regular updating of the internal policy in personal data protection.

The assumptions presented in the article, as well as the prototype concept and program solutions, will be the starting point for further research and development of the navigation system for people inside buildings. The authors plan to prepare more display modules and test the system in a real building in the next step. The result of the tests may arise the need to introduce some changes to improve the system's functionality and reliability.

\section{Acknowledgements}

This work was supported by the National Center for Research and Development, Poland, Grant Agreement EUREKA/
INCREDISCOPE/1/2018 "Smart indoor navigation and access system"

\section{References}

1. MazeMap, [http://mazemap.com]. Last accessed: October 2020 .

2. Biczok G., Martínez S.D., Jelle T., Krogstie J., Navigating MazeMap: indoor human mobility, spatio-logical ties and future potential. [in:] 2014 IEEE International Conference on Pervasive Computing and Communication Workshops (PERCOM WORKSHOPS), 2014, 266-271,

DOI: 10.1109/PerComW.2014.6815215.

3. Gu Y., Lo A., Niemegeers I., A survey of indoor positioning systems for wireless personal networks. "IEEE Communications Surveys \& Tutorials", Vol. 11, No. 1, 2009, 13-32, DOI: 10.1109/SURV.2009.090103.

4. Fallah N., Apostolopoulos I., Bekris K., Folmer E., Indoor human navigation systems: A survey. "Interacting with Computers", Vol. 25, No. 1, 2013, 21-33,

DOI: 10.1093/iwc/iws010.

5. Yin Z., Wu C., Yang Z., Liu Y., Peer-to-peer indoor navigation using smartphones. "IEEE Journal on Selected Areas in Communications", Vol. 35, No. 5, 2017, 1141-1153, DOI: $10.1109 /$ JSAC.2017.2680844.

6. Dong J., Noreikis M., Xiao Y., Ylä-Jääski A., ViNav: A vision-based indoor navigation system for smartphones. "IEEE Transactions on Mobile Computing", Vol. 18, No. 6, 2018, 1461-1475, DOI: 10.1109/TMC.2018.2857772.

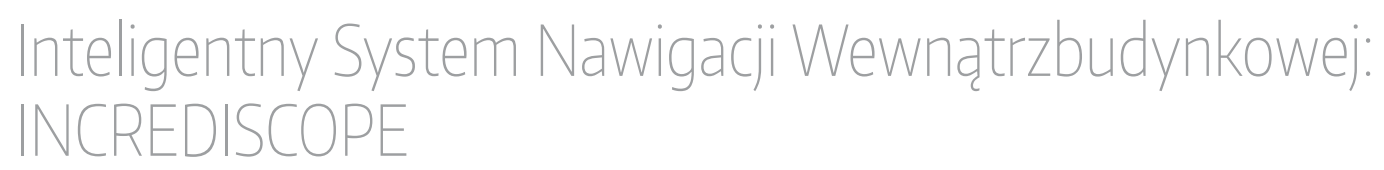

Streszczenie: Artykuł przedstawia ideę nowoczesnego i innowacyjnego na skalę światową systemu nawigacji wewnątrzbudynkowej INCREDISCOPE. System jest w pełni autonomiczny i bazuje na modułach z wyświetlaczami typu e-papier. Dedykowany system lokalizacji oraz nawigacji ludzi wewnątrz budynków pozwala intuicyjnie i naturalnie kierować osoby do wyznaczonego dla nich celu. Artykuł został podzielony na cztery części. Na wstępie zostało podane krótkie wprowadzenie oraz podstawowe założenia projektowanego systemu lokalizacji i nawigacji wewnątrzbudynkowej. W kolejnej części przedstawiono kluczową ideę działania systemu oraz podstawowe założenia i ograniczenia w realizacji tej idei. W trzeciej części artykułu skupiono się na informacjach technicznych na temat stworzonego oprogramowania. W ramach oprogramowania przygotowano trzy różne aplikacje. Pierwsza z nich przeznaczona jest dla administratora systemu, druga przeznaczona jest dla modułów z wyświetlaczami typu e-papier, natomiast ostatnia to aplikacja mobilna dla użytkowników poruszających się ze swoimi smartfonami wewnątrz budynków, w których zainstalowany jest system INCREDISCOPE. Rozpoznawanie użytkowników następuje na podstawie technologii Bluetooth. W artykule przedstawiono dwie wersje interfejsu administratora (Admin 1.0 oraz Admin 2.0). Logika działania każdej z wersji jest całkowicie różna. Pierwsza z nich była zbyt czasochłonna na etapie ustalania relacji między węzłami nawigacji, natomiast druga jest o wiele bardziej intuicyjna. Ostatnia część artykułu to podsumowanie i przedstawienie kierunków dalszego rozwoju systemu. 


\section{PawełDominik, BE}

pawel.dominik@unisystem.pl ORCID: 0000-0002-0205-8885

R\&D manager at the Unisystem, associated with the capital group since 2016. Received two engineer degrees (Mechanical Engineering and Computer Electronic Systems) from the Gdańsk University of Technology. Research area includes optoelectronics, harsh environment HMI, project management, and decision support systems.
Jacek Marcinkowski, MSc Eng.

jacek.marcinkowski@unisystem.pl ORCID: 0000- 0001-6787-3699

Project Manager at Unisystem since 2018 Graduated from Gdańsk University of Technology Microwave and Antenna Engineering Department. Areas of research include project management, optoelectronics, embedded electronics, electromagnetic compatibility.

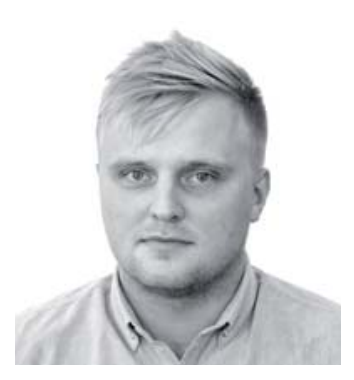

